\title{
Perennial Grasses and Their Response to a Wildfire in South-central Washington
}

\author{
D.W. URESK, W.H. RICKARD, AND J.F. CLINE
}

\section{Abstract}

Three years of past burning responses of three perennial grasses were evaluated by comparing a burned area with an adjacent control (unburned) area. The average leaf length of Cusick bluegrass and Thurber needlegrass was shortened by burning in all 3 years, but leaf shortening was inconsistent for bluebunch wheatgrass. Burning increased the number of flowering culms per clump for Cusick bluegrass during the second year of postburning and for Thurber needlegrass during the third year. The average number of flowering culms per clump in bluebunch wheatgrass was greater in the burned area for all 3 years of postburning. Culm and spike lengths of bluebunch wheatgrass were increased by burning for the first 2 years. Cusick bluegrass and Thurber needlegrass generally responded to burning with shortened culms and spikes. The basal area of Cusick bluegrass and Thurber needlegrass was reduced by burning. Phytomass production of bluebunch wheatgrass showed an increase during the 3 years of postburning, whereas Cusick bluegrass and Thurber needlegrass showed a reduction in phytomass production. No single measurement provided a way to evaluate overall plant responses.

Wildfire is a common event in grasslands which, depending on how, when and where it occurs, may have an important influence on grassland vegetation. Rangemen have often used controlled fire to improve the quantity and quality of livestock forage by eliminating unpalatable but fire sensitive competitive woody species.

Recent literature reviews on fire and its effects on western grasslands are presented by Daubenmire (1968), Vogl (1974), and Vallentine (1974). Daubenmire (1975) reported that burning of bluebunch wheatgrass (Agropyron spicatum) only moderately reduced canopy coverage and frequency, but dry-matter production was reduced $50 \%$ of the unburned area during the first season, with 16 and $17 \%$ reduction during the second and third years of postburning respectively. Mueggler and Blaisdell (1958) reported a 56\% reduction in herbage production of bluebunch wheatgrass 3 years after burning.

Pechanec and Stewart (1944) indicated that bluebunch wheatgrass, Cusick bluegrass (Poa cusickii) and Thurber needlegrass (Stipa thurberiana) were only slightly damaged during the first year after burning, but yield subsequently increased approximately $50 \%$. Wright and Klemmedson

\footnotetext{
Authors are research biologist at Rocky Mountain Forest and Range Experiment Station, South Dakota School of Mines Campus, Rapid City, South Dakota 57701, and senior research scientist and senior research technologist at Battelle, Pacific Northwest Laboratories, Richland, Washington 99352.

Work was performed under contract EY-76-C-06-1830 with the Department of Energy and National Science Foundation Grand GB-31862X2 to the Grassland Biome, U.S. International Biological Program for "Analysis of structure, function, and utilization of grassland ecosystems."

The authors express their thanks to Dr. R.O. Gilbert for help with statistical analysis and to Mr. V.D. Charles, Mrs. M.A. Combs, and Mrs. L.E. Rendall for their field assistance.

Manuscript received December 26, 1978.
}

(1965) reported that the season of burn was important in determining the extent of damage to Thurber needlegrass, but the size of the bunch determined the amount of fire damage. After a wildfire, as high as $90 \%$ of the large plants died but smaller plants survived. Blaisdell (1953) reported that bluebunch wheatgrass was only mildly damaged by burning and within 3 years it had recovered and was producing more herbage on the burned than on unburned areas. Other associated grasses recovered more slowly. Conrad and Poulton (1966) found that crown basal area of bluebunch wheatgrass was reduced $52 \%$ following a burn in an ungrazed area. Fire caused a reduction of plant size but not plant density.

This article reports on the 3-year effects of a wildfire upon a sagebrush-bluebunch wheatgrass community, in the semiarid steppe region of south-central Washington.

\section{Study Area and Methods}

The study area is located on the east-facing slopes of the Lower Rattlesnake Hills within the Arid Lands Ecology (ALE) Reserve of the Department of Energy's Hanford Reservation. The elevation is approximately $396 \mathrm{~m}$ above mean sea level. It receives an average annual precipitation of $23 \mathrm{~cm}$. Rickard et al. (1975) described the study area as a homogenous plant community representative of the Artemisia/Agropyron association. The area was fairly uniform in species composition, plant biomass, slope, exposure, elevation, soil type, and soil chemical properties.

Wildfire initiated by a lightning strike in mid-August 1973, burned through a portion of the study area that had been studied as a control site in conjunction with a grazing study performed with the International Biological Program Grasslands Biome Project. A paved roadway separated the study area into two sections and this prevented the fire from burning through the entire community. For the purpose of this report, a 9-ha served as the control (unburned) and an adjacent 9-ha area served as the burned site. Before 1973, the site had not been burned or grazed by livestock for at least 30 years.

Aboveground phytomass was sampled each spring in the years 1974-1976 in eight randomly selected, $15 \times 30 \mathrm{~m}$ macroplots established in each 9-ha area. Two circular $0.5-\mathrm{m}^{2}$ plot frames were than positioned at random within each of the macroplots and all plants were hand-clipped at ground level. All materials were separated by species. Live and dead phytomass were hand-separated, oven dried, and weighed.

Clumps of bluebunch wheatgrass, Cusick bluegrass, and Thurber needlegrass were measured for length of living (green) leaves, flowering culms, and basal area (length $x$ width) when plants were reproductively mature but not dried from summer drought (Uresk et al. 1976). When measuring bluebunch wheatgrass, six clumps were randomly chosen for measurement if more than six clumps were in one circular frame. If fewer than six clumps occurred inside the circular frame, all clumps were measured.

Cusick bluegrass and Thurber needlegrass were only sparsely represented and in this case the first six clumps encountered in a 
search within each $15 \times 30 \mathrm{~m}$ macroplot were chosen for measurement. All comparisons were subjected to $t$-tests according to the procedures described by Snedecor and Cochran (1967). The three postburning seasons are labeled as first (1974), second (1975), and third (1976).

\section{Results and Discussion}

The response of burning upon the three species of grasses is indicated by morphological characteristics and phytomass production. These characteristics give an indication of plant vigor and reproduction as related to the period after burning occurred.

\section{Precipitation}

Average monthly precipitation during the three growing seasons after burning is presented in Table 1. The portion of the year considered most influential to plant growth is the period October through May. The first growing season after burning was much wetter than the second and third: $34 \mathrm{~cm}$ of precipitation as compared to 24 and 20 , which obviously affected the results.

\section{Leaf Length}

Burning reduced the average leaf lengths for all three species of grasses (Table 2). Bluebunch wheatgrass responded to burning with shorter average leaf lengths especially in 1974, the first year of postburning. However, during the second year, the burned and control plots had similar leaf lengths. Burning reduced leaf lengths of Cusick bluegrass and Thurber needlegrass in all three years of postburning, but the greatest differences were measured during the first year. Thurber needlegrass showed the greatest sensitivity to burning insofar as indicated by shorter leaves.

Thurber needlegrass also showed the slowest recovery rates over the 3 year perod of postburning (Fig. 1). It will evidently require several more years of recovery before burned plants again produce leaves of normal length. Leaf lengths of bluebunch wheatgrass and Cusick bluegrass were approximately equal to the unburned plants by the second and third years of postburning, respectively.

\section{Culm Length}

The flowering culms of bluebunch wheatgrass were substantially taller in the burned plots than in the unburned plots in the first and second years of postburning (Table 2). However, during the third year, the culms were slightly shorter on the burned plots. Cusick bluegrass showed a significant increase in culm length during the second year. Culm length of Thurber needlegrass averaged shorter on the burned area than on the unburned during the 3 years after burning. Figure 1 shows the yearly percent changes in recovery when compared to the unburned plots. Bluebunch wheatgrass and Cusick bluegrass show culm lengths returning to plants on the control during the third year of postburning, while Thurber needlegrass will require several additional years before culm lengths are similar to those in the unburned area.
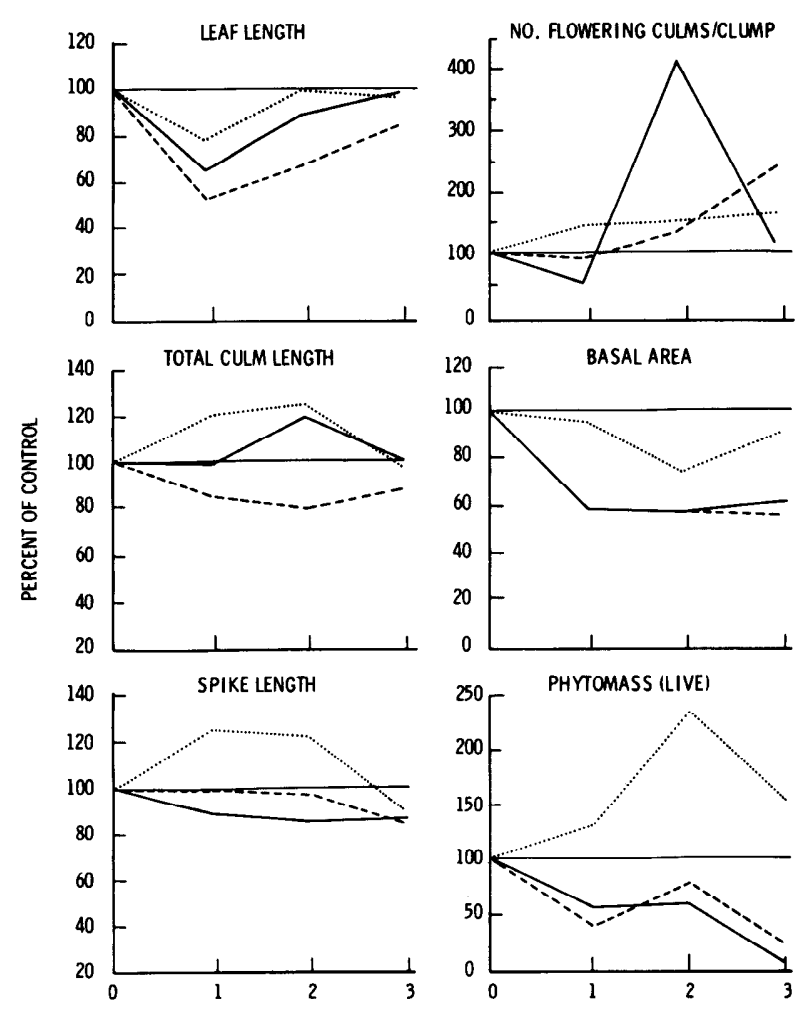

YEARS AFTER WILDFIRE

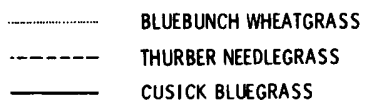

Fig. 1. Recovery of bluebunch wheatgrass, Thurber needlegrass and Cusick bluegrass for 3 years after a wildfire for leaf length, total culm length spike length, number of flowering culms per clump, basal area, and phytomass (live).

\section{Spike length}

Bluebunch wheatgrass responded to burning by having longer spikes during the first 2 years after burning but showed a significant decrease during the third year (Table 2). Cusick bluegrass showed negative response to burning, spikes were shorter throughout the 3-year postburning period. The spikes of Thurber needlegrass did not respond to burning during the first 2 years, but showed a decrease during the third year of postburning.

The percent change in spikes, when compared to the unburned area, is presented in Figure 1 for all three species. The change in spike length for all three species was shorter during the third year after burning, but was approximately $84-89 \%$ of the control.

\section{Number of Flowering Culms Per Clump}

Generally, the number of flowering stalks per clump showed an increase for all three species by the second year of

Table 1. Monthly precipitation (cm) during three growing seasons of post-burning.

\begin{tabular}{lcccccccccccccccccc}
\hline \hline Year & Oct & Nov & Dec & Jan & Feb & Mar & Apr & May & $\begin{array}{c}\text { Sub } \\
\text { Total }\end{array}$ & Jun & Jul & Aug & Sep & Total \\
\hline $1973-74$ & 4.3 & 8.0 & 8.4 & 4.3 & 4.2 & 2.8 & 1.4 & 0.6 & $(34.0)$ & 0.2 & 1.5 & 0 & 0 & 35.7 \\
$1974-75$ & 0.4 & 3.0 & 3.5 & 5.5 & 3.8 & 4.2 & 2.5 & 1.2 & $(24.1)$ & 1.4 & 0.3 & 2.9 & $<.1$ & 28.7 \\
$1975-76$ & 3.1 & 3.3 & 3.0 & 3.0 & 3.1 & 1.9 & 1.8 & 0.6 & $(19.8)$ & 0.3 & 0.9 & 1.8 & $<.1$ & 22.8 \\
\hline
\end{tabular}


Table 2. Average leaf length, total culm length, spike length, number of flowering culms per clump, basal area and phytomass measured in burned and adjjacent control plots during three years of post-burning. (mean \pm standard error)

\begin{tabular}{|c|c|c|c|c|c|c|}
\hline \multirow[b]{2}{*}{ Year } & \multicolumn{2}{|c|}{ Bluebunch wheatgrass } & \multicolumn{2}{|c|}{ Cusicks bluegrass } & \multicolumn{2}{|c|}{ Thurber needlegrass } \\
\hline & Burn & Control & Burn & Control & Burn & Control \\
\hline \multicolumn{7}{|c|}{ Total Leaf Length (cm) } \\
\hline 1974 & $23.9 \pm 0.3^{* *}$ & $31.1 \pm 0.3$ & $14.1 \pm 0.2^{* *}$ & $21.9 \pm 0.2$ & $14.3 \pm 0.2^{* *}$ & $27.5 \pm 0.3$ \\
\hline 1975 & $28.7 \pm 0.3$ & $29.3 \pm 0.2$ & $17.5 \pm 0.1^{* *}$ & $20.2 \pm 0.2$ & $16.8 \pm 0.2^{* *}$ & $25.8 \pm 0.2$ \\
\hline 1976 & $26.5 \pm 0.3^{* *}$ & $28.1 \pm 0.3$ & $18.5 \pm 0.2^{* *}$ & $19.2 \pm 0.2$ & $17.1 \pm 0.2^{* *}$ & $21.1 \pm 0.2$ \\
\hline \multicolumn{7}{|c|}{ Total Culm Length $(\mathrm{cm})$} \\
\hline 1974 & $51.9 \pm 0.4^{* *}$ & $43.4 \pm 1.0$ & $46.6 \pm 0.8$ & $46.9 \pm 0.6$ & $37.9 \pm 0.5^{* *}$ & $44.7 \pm 0.5$ \\
\hline 1975 & $51.3 \pm 0.5^{* *}$ & $41.7 \pm 0.7$ & $43.4 \pm 0.5^{* *}$ & $36.9 \pm 1.4$ & $29.6 \pm 0.6^{* *}$ & $37.3 \pm 1.1$ \\
\hline 1976 & $44.0 \pm 0.5^{* *}$ & $46.3 \pm 0.7$ & $41.9 \pm 0.5$ & $42.5 \pm 0.5$ & $27.0 \pm 0.4^{* *}$ & $31.5 \pm 0.7$ \\
\hline \multicolumn{7}{|c|}{ Spike Length (cm) } \\
\hline 1974 & $8.1 \pm 0.1^{* *}$ & $6.5 \pm 0.2$ & $5.7 \pm 0.1^{* *}$ & $6.4 \pm 0.1$ & $9.9 \pm 0.1$ & $9.9 \pm 0.2$ \\
\hline 1975 & $7.9 \pm 0.1^{* *}$ & $6.5 \pm 0.2$ & $5.8 \pm 0.1^{* *}$ & $6.8 \pm 0.2$ & $9.1 \pm 0.2$ & $9.4 \pm 0.3$ \\
\hline 1976 & $6.5 \pm 0.1^{* *}$ & $7.3 \pm 0.2$ & $5.6 \pm 0.1^{* *}$ & $6.5 \pm 0.1$ & $6.5 \pm 0.1^{* *}$ & $7.7 \pm 0.2$ \\
\hline \multicolumn{7}{|c|}{ Number Flowering Culms per Clump } \\
\hline 1974 & $36.4 \pm 7.8$ & $25.7 \pm 6.5$ & $6.5 \pm 1.2^{* *}$ & $13.2 \pm 2.5$ & $13.6 \pm 1.1$ & $15.4 \pm 1.6$ \\
\hline 1975 & $37.9 \pm 5.5$ & $25.9 \pm 5.4$ & $17.5 \pm 4.3^{*}$ & $4.3 \pm 1.0$ & $6.6 \pm 1.1$ & $5.1 \pm 1.0$ \\
\hline 1976 & $19.8 \pm 3.7$ & $12.7 \pm 2.7$ & $8.5 \pm 1.6$ & $7.8 \pm 1.5$ & $9.2 \pm 1.3^{* *}$ & $4.0 \pm 0.5$ \\
\hline \multicolumn{7}{|c|}{ Basal Area $(1 \times \mathrm{w})^{1} \mathrm{~cm}^{2}$} \\
\hline 1974 & $244 \pm 41$ & $257 \pm 47$ & $220 \pm 23^{* *}$ & $382 \pm 35$ & $52 \pm 6^{* *}$ & $90 \pm 8$ \\
\hline $\begin{array}{l}1975 \\
1976\end{array}$ & $293 \pm 48^{*}$ & $402 \pm 52$ & $183 \pm 20^{* *}$ & $324 \pm 29$ & $45 \pm 5^{* *}$ & $81 \pm 8$ \\
\hline & $298 \pm 66$ & $337 \pm 55$ & $169 \pm 16^{* *}$ & $285 \pm 22$ & $40 \pm 4^{* *}$ & $75 \pm 8$ \\
\hline \multicolumn{7}{|c|}{ Phytomass (live) $\mathrm{g} / \mathrm{m}^{2}$} \\
\hline 1974 & $61.1 \pm 10.2$ & $46.6 \pm 9.6$ & $2.4 \pm 1.1$ & $4.3 \pm 3.8$ & $0.9 \pm 0.5$ & $2.3 \pm 2.1$ \\
\hline 1975 & $80.7 \pm 12.6^{* *}$ & $34.3 \pm \quad 3.7$ & $1.5 \pm 1.4$ & $2.5 \pm 2.0$ & $1.1 \pm 0.7$ & $1.4 \pm 0.6$ \\
\hline 1976 & $42.6 \pm 3.8^{* *}$ & $27.4 \pm 3.6$ & $0.3 \pm 0.2^{*}$ & $4.1 \pm 2.0$ & $0.1 \pm 0.1$ & $0.4 \pm 0.4$ \\
\hline \multicolumn{7}{|c|}{ Phytomass (dead) $\mathrm{g} / \mathrm{m}$} \\
\hline 1974 & 0 & $58.6 \pm 12.5$ & 0 & $3.8 \pm 3.4$ & $\mathbf{0}$ & $1.0 \pm 1.0$ \\
\hline 1975 & $49.8 \pm 6.9$ & $46.5 \pm 5.7$ & 0 & $1.0 \pm 0.7$ & $0.5 \pm 0.5$ & $1.4 \pm 0.6$ \\
\hline 1976 & $67.3 \pm 8.4$ & $48.6 \pm 8.0$ & $0.4 \pm 0.2^{*}$ & $5.5 \pm 2.3$ & $0.1 \pm 0.1$ & 0 \\
\hline \multicolumn{7}{|c|}{ Percentage of Clumps with Flowering Culms } \\
\hline 1974 & 86 & 74 & 67 & 72 & 100 & 100 \\
\hline 1975 & 85 & 90 & $69^{* *}$ & 31 & $75^{* *}$ & 38 \\
\hline 1976 & 67 & 65 & 60 & 65 & 88 & 69 \\
\hline
\end{tabular}

* Significantly different from control at .05 level

** Significantly different from control at the .01 level

$1 \times w=$ length $\times$ width; Statisical tests performed on log transformations.

postburning (Table 2). Bluebunch wheatgrass showed an increase in the number of flowering culms per clump throughout the 3 years of restoration. Cusick bluegrass produced the largest number of culms on the burned area during the second year while Thurber needlegrass had the highest number of culms during the third year of postburning. The response rates expressed as a percent of the control are presented in Figure 1 for each species. Bluebunch wheatgrass showed an increase in flowering culms of approximately $50 \%$ above the plants in the unburned area during the 3 years after burning. Thurber needlegrass showed a $130 \%$ increase by the third year in number of flowering culms per clump. These data suggest that several more years may be required before bluebunch wheatgrass and Thurber needlegrass will be approximately the same for flowering culms as the plants on the unburned area.

\section{Percentage of Clumps with at Least One Flowering Culm}

Burning did not reduce the percentage of bluebunch wheatgrass having a flowering culm (Table 2). Yearly differences did occur in the number of clumps with flowering culms, with plants measured in 1976 having the lowest percentage of clumps with culms on both burned and unburned areas. This was also the driest of the 3 years. Cusick bluegrass had an increase of 38 percentage units of clumps occurring with culms during the second year of postburning. However, by the third year no difference occurred. Thurber needlegrass showed that during the first year following the burn, all clumps had flowering culms. During the second and third years, Thurber needlegrass showed a higher percentage of clumps with flowering culms on the burned area.

\section{Basal Area}

The basal area of bluebunch wheatgrass showed a significant reduction on the burned area during the second year after burning (Table 2). However, the basal area of Cusick bluegrass and Thurber needlegrass were significantly reduced by burning for all three years of postburning. Fire was more detrimental to basal areas of Cusick bluegrass and Thurber needlegrass than to bluebunch wheatgrass (Fig. 1). It appears that no or very little response has occurred with either Cusick bluegrass or Thurber needlegrass after the first year of postburning. 


\section{Phytomass}

The production of bluebunch wheatgrass was increased by burning. The burned plots produced more live phytomass than the unburned plots (Table 2). The most pronounced difference occurred during the second year of postburning when $135 \%$ more biomass was harvested on the burned area as compared to the unburned area. The average annual biomass production of bluebunch wheatgrass on the burned plots ranged from $43 \mathrm{~g} / \mathrm{m}^{2}$ to $81 \mathrm{~g} / \mathrm{m}^{2}$; on the unburned plot the averages ranged from 27 $\mathrm{g} / \mathrm{m}^{2}$ to $47 \mathrm{~g} / \mathrm{m}^{2}$ over the 3-year postburning period. Production estimates of Cusick bluegrass and Thurber needlegrass were highly variable for these sparsely represented plants in the community. However, general trends indicate that these two species show a negative response to burning (Fig. 1).

This particular fire effectively removed all standing dead bluebunch wheatgrass so there was no residual dead grass on the burned plots at the end of the 1974 season (Table 2). However, most of the $61 \mathrm{~g} / \mathrm{m}^{2}$ production during the first postburning season was still present i.e. $50 \mathrm{~g} / \mathrm{m}^{2}$ at the beginning of the second season. Standing dead grass at the end of the third season averaged $67 \mathrm{~g} / \mathrm{m}^{2}$ indicating that the older portions of standing dead material had been largely transferred to litter. The standing dead phytomass in the control plots ranged between 46 and $59 \mathrm{~g} / \mathrm{m}^{2}$ indicating that about $50 \mathrm{~g} / \mathrm{m}^{2}$ is a reasonable estimate of standing dead material for bluebunch wheatgrass in this area. The average live production amounted to only $36 \mathrm{~g} / \mathrm{m}^{2}$ for the three-year period. This was close to the $42 \mathrm{~g} / \mathrm{m}^{2}$ produced during the years 1971 to 1974 (Rickard et al. 1976).

\section{Other Observations and Relationships to Other Studies}

Wildfire is a natural event that usually occurs during late summer months when grasses are mature and dry from summer drought in the steppe region of south-central Washington. The main natural cause of fire is lightning associated with summer storms that typically produce little or no rainfall at the ground surface. The principal persistent change to sagebrushbluebunch wheatgrass vegetation is the demise of sagebrush. Uresk et al. (1977) estimated the standing crop of sagebrush at $69 \pm 16 \mathrm{~g} / \mathrm{m}^{2}( \pm \mathrm{SE})$. Once sagebrush is burned, the recolonization of the burned land is through seeds. There is no indication that sagebrush was quickly invading the burned area through seed dispersal from the few plants that had escaped burning. However, invasion by sagebrush may occur in later years. Although some clumps of perennial grasses were killed, most survived the burning and were vigorous plants during the spring following the late summer burn. There was also no invasion by weedy species such as Bromus tectorum.

Bluebunch wheatgrass is the most abundant grass in the sagebrush-bluebunch wheatgrass association. Although it is not as palatable as Cusick bluegrass (Uresk and Rickard 1976), it is more important in terms of total forage production (Rickard et al. 1975). Because the burning occurred in August, there was little green material other than the crown itself and almost all the photosynthetic and growth activity had been conducted prior to burning. It seems likely that the quick response of recovery following burning was increased by the very favorable moisture regime of the 1973-1974 season and because of the failure of this wildfire to damage crown meristematic tissues. Judging from the reduction of basal area of Cusick bluegrass and Thurber needlegrass these two grasses were more damaged by burning than was bluebunch wheatgrass.

Although burning appeared to have no deleterious impact upon bluebunch wheatgrass as described by Daubenmire (1975) and Mueggler and Blaisdell (1958), it is not certain in our investigation if the results would have been the same if the following growing season had been a drier than average year rather than a wetter than average year.

From the results of this study, it seems clear that different perennial grasses respond to wildfire burning in different ways and that no single measurement we tried appears to provide a way to evaluate overall plant responses.

\section{Literature Cited}

Blaisdell, J.P. 1953. Ecological effects of planned burning of sagebrushgrass range on the upper Snake River plains. U.S. Dep. Agr., Tech. Bull. 1075. $30 \mathrm{p}$.

Conrad, C.E., and C.E. Poulton. 1966. Effects of a wildfire on a Idaho fescue and bluebunch wheatgrass. J. Range Manage. 19:138-141.

Daubenmire, R. 1968. Ecology of fire in grasslands. Advanc. in Ecol. Res. 5:209-266.

Daubenmire, R. 1975. Plant succession on abandoned fields and fire influences in a steppe årea in southeastern Washington. Northwest Sci. 49: 36-48.

Mueggler, W.F. and J.P. Blaisdell. 1958. Effects on associated species of burning, rotobeating, spraying and railing sagebrush. J. Range Manage. 11:61-66.

Pechanec, J.F., and G. Stewart. 1944. Sagebrush burning-good and bad. U.S. Dep. Agr. Farmers Bull. 1948. 32 p.

Rickard, W.H., D.W. Uresk, and J.F. Cline. 1975. Impact of cattle grazing on three perennial grasses in south-central Washington. J. Range Manage. 28:108-112.

Rickard, W.H., D.W. Uresk, and J.F. Cline 1976. Productivity response to precipitation by native and alien plant communities. In Proc. of Sym. on Terr. and Aquat. Ecol. Studies of the Northwest. March 26-27, 1976. East. Wash. State Coll. Cheney, Wash. p. 1-7.

Snedecor, G.W., and W.G. Cochran. 1967. Statistical methods. lowa State Univ. Press. 115-116 p.

Uresk, D.W., J.F. Cline, and W.H. Rickard. 1976. Impact of wildfire on three perennial grasses in south-central Washington. J. Range Manage. 29:309-310.

Uresk, D.W., and W.H. Rickard. 1976. Diets of steers on a shrubsteppe rangeland in south-central Washington. J. Range Manage. 29:464466.

Uresk, D.W., R.O. Gilbert, and W.H. Rickard. 1977. Sampling big sagebrush for phytomass. J. Range Manage. 30:311-314.

Vallentine, J.F. 1974. Range development and improvements. Brigham Young Univ. Press, Provo, Utah. 516 p.

Vogl, R.J. 1974. Effects of fire on grasslands, p. 139-194. In: Fire and ecosystems. T.T. Kozlowski and C.E. Ahlgren (Eds.). Acad. Press, New York.

Wright, H.A., and J.O. Klemmedson. 1965. Effect of fire on bunchgrasses of the sagebrush-grass region in southern Idaho. Ecology 46 : 680-688. 